Dragiša Jaćimović, kapetan I klase, dipl. inž.

Zoran Despotović, dipl. inž.

Tehnički remontni zavod,

\section{TEHNOLOGIJA I PROCEDURA UNIŠTAVANJA NAORUŽANJA MALOG KALIBRA}

UDC: $623.442 / .443: 351.753 .7$

Rezime:

U radu su predstavljene standardne tehnologije i procedure koje se primenjuju pri uništavanju naoružanja malog kalibra u Tehničkom remontnom zavodu Čačak. One obuhvataju proces prijema i identifikacije, postupke demontaže i plastične deformacije na hidropneumatskim presama i gasnog sečenja cevi većih kalibara, kao i primenjene načine označavanja $i$ skladištenja svih vrsta nastale furde-otpada. Ova metoda uništavanja naoružanja prošla je strogu medunarodnu verifikaciju $i$ u konkurenciji sa drugim predloženim metodama prihvaćena je kao najbolje rešenje za date uslove $i$ zahteve. Takođe, prikazane su $i$ posebne mere zaštite na radu koje je zahtevao naručilac radova, a primenjene su u toku procesa uništavanja naoružanja.

Ključne reči: uništavanje naoružanja, plastična deformacija, hidropneumatska presa, gasno sečenje, otpadni materijal, zaštita na radu.

\title{
TECHNOLOGIES AND PROCEDURES APPLIED IN DESTROYING SMALL ARMS
}

Summary:

This work is a presentation of standard technologies and procedures used in a process of small arms destruction in the Technical Repair Bureau Ččak. They include item reception and identification, dismantling and plastic deformation on a hydro-pneumatic press and gas cutting of large-caliber tubes well as marking and warehousing waste materials of all kinds. This method of weapon destruction has passed several international verification controls and in comparison with other suggested methods, it has been accepted as the best solution for particular conditions and requirements. Some special protective measures in the process of weapon destruction, applied at customer's requests, have been presented as well.

Key words: weapon destruction, plastic deformation, hydropneumatic press, gas cutting, waste material, protection at work.

\section{Uvod}

U periodu od 2001. do 2004. godine u Tehničkom remontnom zavodu u Čač$\mathrm{ku}$, u okviru realizacije ugovora Ministarstva odbrane SCG sa međunarodnim organizacijama za kontrolu naoružanja i ambasadama zapadnih zemalja, u više navrata vršeno je uništavanje malog i lakog naoružanja, zaključno sa kalibrom
$82 \mathrm{~mm}$. Ove akcije su se odvijale sukcesivno i obuhvatale su uništavanje uglavnom zastarelog, neperspektivnog i suvišnog naoružanja. Metode uništavanja koje se sprovode u TRZ Čačak prošle su strogu međunarodnu verifikaciju i u konkurenciji sličnih metoda pokazale se kao najlakše kontrolisane $u$ svim fazama procesa i najrentabilnije sa stanovišta troškova rada i materijala. 
Pored sprovođenja propisanih tehnologija i dogovorenih metoda uništavanja naoružanja, inostrani predstavnici koji su nadzirali uništavanje posebno su insistirali na strogoj primeni mera zaštite na radu. To se posebno odnosi na rad na hidropneumatskim presama pri izvođenju plastičnih deformacija pojedinih sklopova naoružanja. U skladu s tim zahtevom vršeno je projektovanje i ugradnja zaštitnih ograda i mehanizama u zoni dejstava presa za plastično deformisanje.

U okviru predstavljanja aktivnosti uništavanja naoružanja vršena je odgovarajuća prezentacija za predstavnike Ministarstva odbrane i međunarodne verifikatore i donatore, čiji je grafički deo predstavljen u ovom radu.

\section{Tehnologija i procedura uništavanja naoružanja}

Proces uništavanja naoružanja započinje prijemom sredstva predviđenog za uništavanje. Naoružanje se pojedinačno evidentira i smešta $u$ odgovarajuće sanduke koji se obeležavaju. Nakon formiranja zapisnika o prijemu i drugih materijalnih dokumenata za određenu primljenu količinu naoružanja (materijalne liste, razduženja tehničkih knjižica sa delovima IK i RAP-a i dr.) ono se skladišti u odgovarajući magacinski prostor do trenutka uništavanja. Nakon toga naoružanje se u sanducima dovozi u prostor za uništavanje, gde ga preuzima ekipa koja obavlja ovaj proces. Sa naoružanjem se šalje i odgovarajući zapisnik koji je formiran pri prijemu, koji ujedno služi kao revers kojim rukovalac skladišta predaje naoružanje na proces uništavanja.
Članovi ekipe za uništavanje, zaduženi za identifikaciju naoružanja, pojedinačno upoređuju fabrički broj svakog oružja sa zapisnikom, evidentiraju u odgovarajućoj rubrici da je naoružanje uzeto u proces uništavanja, vrše proveru ispražnjenosti od eventualno zaostale munucije i smeštaju naoružanje u pokretnu sošku. Ukoliko se neki fabrički broj pojedinačnog naoružanja ne može sravniti sa zapisnikom o prijemu, ono se vraća rukovaocu, usaglašava stanje sa komisijom za prijem i vrše potrebne ispravke. Kada se soška napuni (ili pregleda i isprazni odgovarajuća količina sanduka), doprema se pored radnog stola gde se vrši demontaža (rastavljanje) naoružanja. Istovremeno, obavlja se i sortiranje odgovarajućeg RAP-a koji je u sanducima došao sa naoružanjem, tako da se odvajaju metalni, drveni, kožni, plastični i drugi delovi furde u posebne sanduke koji se, takođe, obeležavaju.

$\mathrm{Na}$ liniji demontaže vrši se rastavljanje naoružanja od kojih se vitalni delovi, kao što su cev, zatvarač, udarna igla i sl. smeštaju u odgovarajuće sanduke koji se obeležavaju tako što im se daje oznaka soške sa kojih je skinuto naoružanje od kojih oni potiču. Ostali delovi se razvrstavaju prema vrstama materijala (metal, drvo, koža, plastika i sl.) i pakuju i obeležavaju kao i furda nastala od delova IK i RAP-a.

Delovi malog i lakog naoružanja, izrađeni od presovanog lima ili cevi tankih zidova, uništavaju se plastičnom deformacijom. Deformacija se izvodi na ekscentarskim i frikcionim hidropneumatskim presama sa minimalnim silama od $600 \mathrm{kN}$. Naoružanje debelih i masivnih zidova uništava se presecanjem.

Presecanje se vrši: gasnim rezačima, elektrolučno, korišćenjem elektroda za rezanje, i abrazivnim brusnim pločama. 
Organizacija procesa uništavanja naoružanja malog kalibra prikazana je na slici 1.

Postupak plastičnog deformisanja vitalnih delova naoružanja na hidropneumatskim presama predstavlja najvažniju fazu u procesu uništavanja naoružanja. Tehnološke prednosti uništavanja naoružanja metodom plastičnog deformisanja ogledaju se u tome da se sa jednim ili više relativno jednostavnih hodova izvršnog dela mašine (pritiskivača prese) vrši narušavanje površinske strukture metalnih i drugih delova naoružanja i time njegovo potpuno onesposobljavanje za ponovno sklapanje i upotrebu. Istovremeno, prednost metode plastične deformacije je mala količina otpada koja je maseno ekvivalentna masi naoružanja u sklopljenom stanju, i kao takva može se lako obeležiti i evidentirati.

\section{Zahtevi pri uništavanju naoružanja}

Postupkom uništavanja naoružanja mora se obezbediti:

- uništenje svih vitalnih delova;

- da maksimalna dužina nedeformisanog dela plastičnom deformacijom ne bude veća od $50 \mathrm{~mm}$ kod pištolja, a kod pušaka i mitraljeza ne veća od $100 \mathrm{~mm}$,

- da posle sečenja vitalnih delova naoružanja (cevi, brave, zatvarača, podloge, dvonošca i sl.), opravka i regeneracija takvih delova ne bude moguća.

Raspored mesta deformacije na lakom naoružanju prikazan je na slici 2 .

Tehnološki postupak uništavanja naoružanja deformacijom na hidropneumatskim presama i gasnim sečenjem prikazan je u tabeli.

Raspored mesta sečenja naoružanja kalibra većeg od 7,9 mm prikazan je na slici 3 .

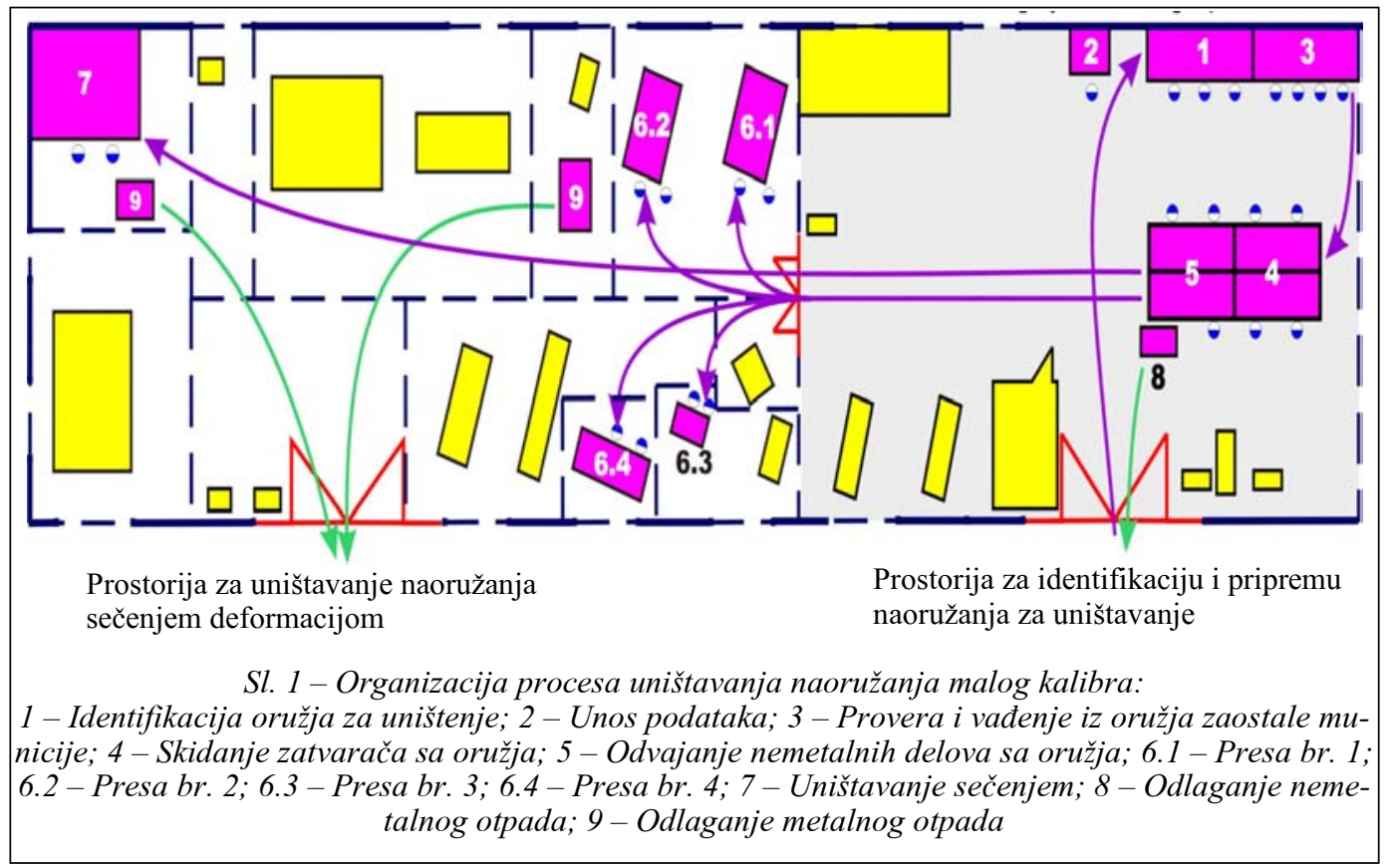




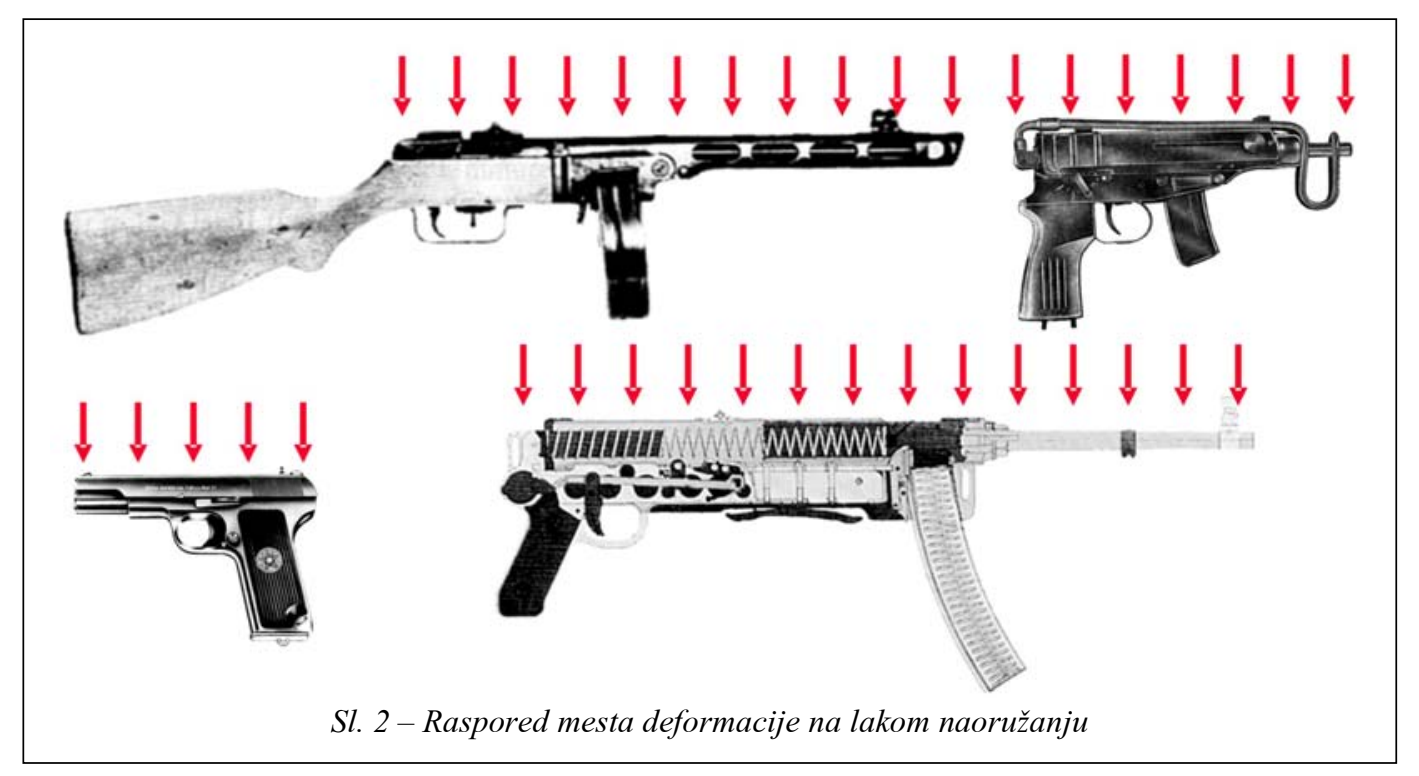

Tehnološki postupak uništavanja naoružanja deformacijom na hidropneumatskim presama i gasnim sečenjem

\begin{tabular}{|c|c|c|c|c|c|c|}
\hline \multirow{3}{*}{$\begin{array}{l}\text { Red. } \\
\text { br. }\end{array}$} & \multirow{3}{*}{ Aktivnost - tehnološka operacija } & \multicolumn{5}{|c|}{ Vreme rada (tehnički normativ) } \\
\hline & & \multicolumn{2}{|c|}{ NČ/izvršilac } & \multirow{2}{*}{$\begin{array}{l}\text { Broj } \\
\text { izvršil. }\end{array}$} & \multicolumn{2}{|c|}{ Ukupno NČ/kom } \\
\hline & & sati & minuta & & sati & minuta \\
\hline 1. & $\begin{array}{l}\text { Izdvajanje odgovarajućeg naoružanja u skladištu, po } \\
\text { tipovima }\end{array}$ & 0,033 & 2,00 & 3 & 0,100 & 6,00 \\
\hline 2. & $\begin{array}{l}\text { Utovar i transport naoružanja do mesta uništenja i } \\
\text { istovar }\end{array}$ & 0,033 & 2,00 & 3 & 0,100 & 6,00 \\
\hline 3. & $\begin{array}{l}\text { Identifikacija naoružanja (utvrđivanje modela, kali- } \\
\text { bra, serijskog broja i količine) i unos podataka u } \\
\text { specifikacije }\end{array}$ & 0,05 & 3,00 & 4 & 0,200 & 12,00 \\
\hline 4. & $\begin{array}{l}\text { Provera i vađenje iz naoružanja zaostale municije } \\
\text { (iz cevi i okvira) }\end{array}$ & 0,05 & 3,00 & 4 & 0,200 & 12,00 \\
\hline 5. & $\begin{array}{l}\text { Skidanje zatvarača i okvira sa naoružanja i njihovo } \\
\text { odlaganje }\end{array}$ & 0,0166 & 1,00 & 4 & 0,066 & 4,00 \\
\hline 6. & $\begin{array}{l}\text { Odvajanje nemetalnih delova sa naoružanja (drve- } \\
\text { nih, plastičnih, kožnih i platnenih), njihova selekcija } \\
\text { i odlaganje u ambalažu }\end{array}$ & 0,083 & 5,00 & 1 & 0,083 & 5,00 \\
\hline 7. & $\begin{array}{l}\text { Uništavanje deformacijom ili gasnim sečenjem vi- } \\
\text { talnih sklopova na naoružanju, u sklopljenom stanju, } \\
\text { prema šemi uništenja }\end{array}$ & 0,033 & 2,00 & 4 & 0,133 & 8,00 \\
\hline 8. & $\begin{array}{l}\text { Razvrstavanje i odlaganje u ambalažu furde nastale } \\
\text { uništavanjem naoružanja, zatvarača i okvira }\end{array}$ & 0,033 & 2,00 & 2 & 0,066 & 4,00 \\
\hline 9. & $\begin{array}{l}\text { Utovar, transport u skladište i istovar furde nastale } \\
\text { uništavanjem naoružanja i nemetalnih delova }\end{array}$ & 0,025 & 1,50 & 2 & 0,05 & 3,00 \\
\hline 10. & $\begin{array}{l}\text { Planiranje, organizacija, praćenje radova i izrada iz- } \\
\text { veštaja o uništenju naoružanja }\end{array}$ & 0,0083 & 0,50 & 1 & 0,0083 & 0,50 \\
\hline \multicolumn{5}{|c|}{ U K U P N O } & 1,0063 & 60,5 \\
\hline
\end{tabular}




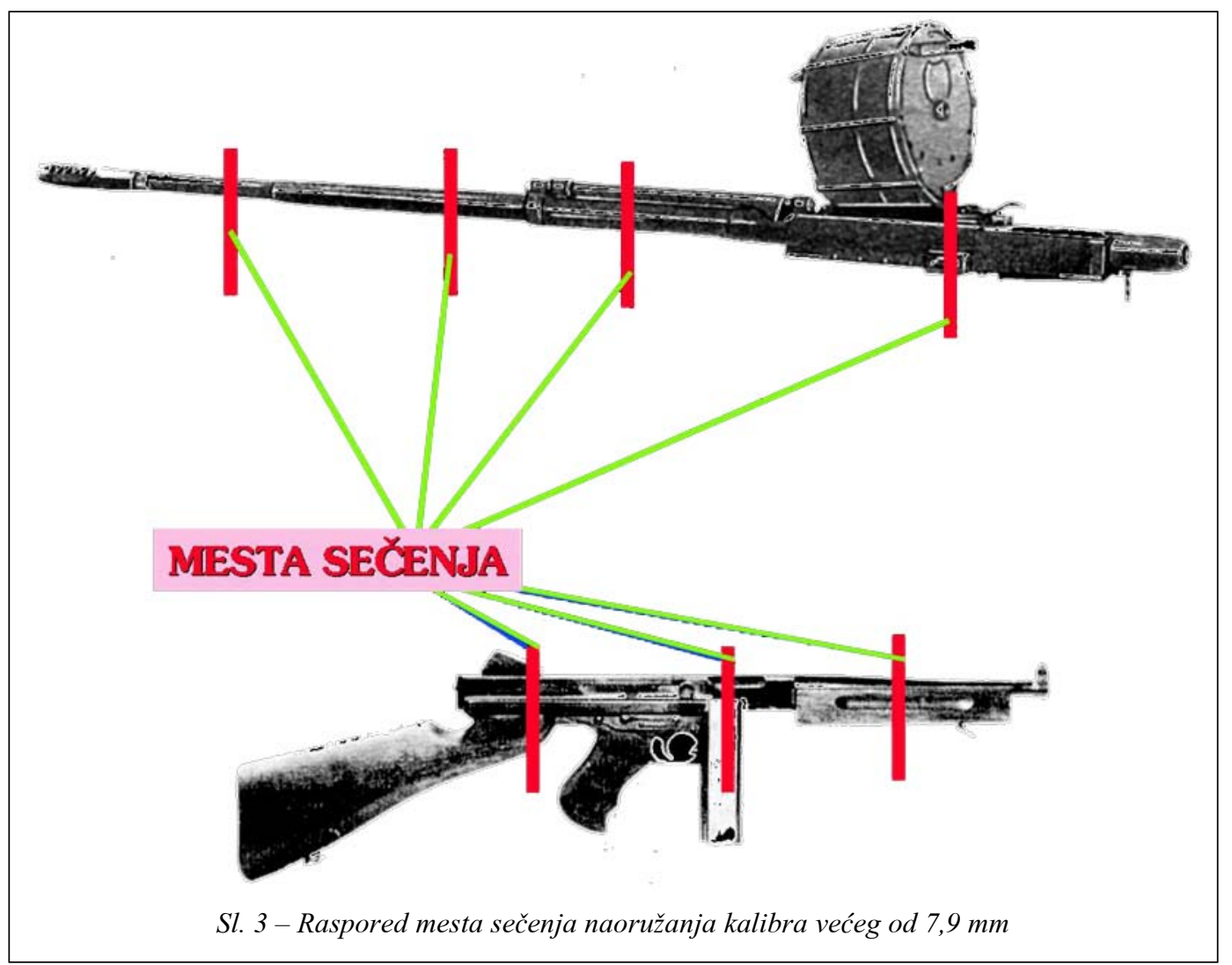

\section{Šematski prikaz postupka uništavanja naoružanja}

Tehnološki proces uništavanja naoružanja određen je nizom definisanih radnji i postupaka. Načelna šema i tok postupka uništavanja, po fazama, prikazani su na slici 4.

\section{Odlaganje i obeležavanje otpada}

Pri uništavanju naoružanja nastaju različite vrste otpada. Pored metalnog otpada koji je najzastupljeniji, u procesu uništavanja naoružanja nastaje drveni, krpeno-platneni, kožni, gumeni, plastični i drugi otpad koji se poje- dinačno evidentira, meri i uz materijalnu listu razdužuje kod rukovaoca, kao i pri svakom drugom postupku rashodovanja.

Pri uništavanju naoružanja, pored standardnih postupaka sa otpadom, koji su navedeni u skladu sa Uputstvom o materijalno-finansijskom poslovanju, reguliše se i postupak sa:

- gorivom i mazivima preostalim iz sredstava koja se uništavaju;

- tehničkim knjižicama i kartonima;

- delovima koji se skladište u odgovarajućim magacinima (noževi, okviri, četkice, izbijači, čistilice, kantice i sl.).

Odlaganje uništenog naoružanja prikazano je na slici 5. 


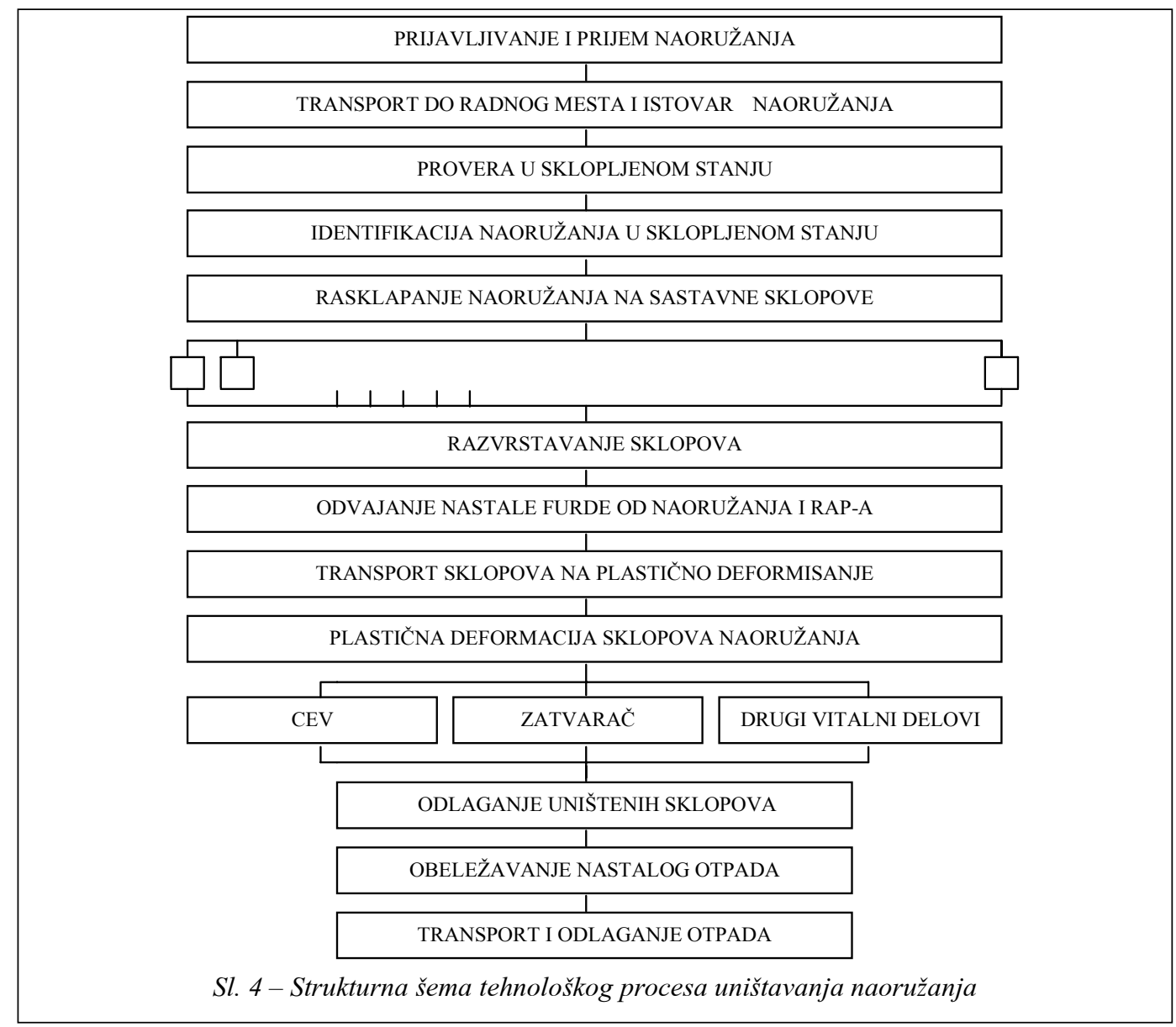

\section{Alternativne metode uništavanja naoružanja}

Istaknuto je da su metode uništavanja naoružanja primenjene u Tehničkom remontnom zavodu u Čačku prošle strogu međunarodnu verifikaciju i pokazale se kao konkurentne drugim metodama. Međutim, u praksi se primenjuju i druge metode uništavanja, kao što su:

- topljenje u visokim pećima,

- uništavanje dejstvom jakih kiselina ili baza,

- direktno sečenje na presama velikih snaga, zilima,

- metoda „gaženja“" guseničnim vo-

- potapanje u more na velikim dubinama i sl.

Nabrojane metode, a i mnoge druge, u poređenju sa metodom koja se primenjuje u TRZ Čačak imaju mnogo nedostataka, koji su najčešće izraženi u nemogućnosti naknadne kontrole fabričkih brojeva naoružanja koje je uništeno, jer se samim postupkom uništavanja gube svi tragovi o tipu, fabričkom broju, modelu i drugi bitni podaci koji bi se i nakon određenog perioda mogli koristiti i biti proveravani. 


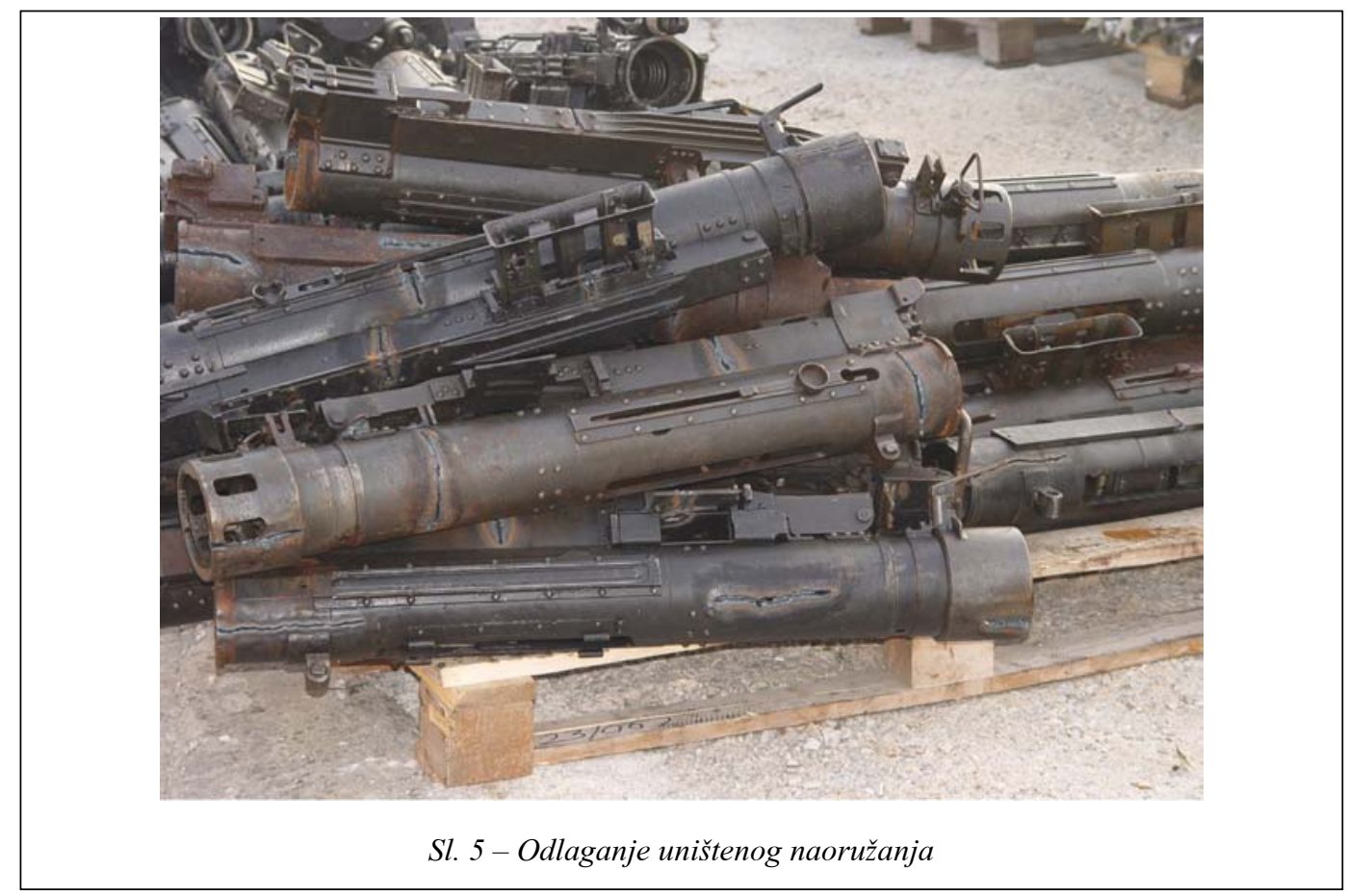

\section{Mere i postupci zaštite na radu pri uništavanju naoružanja}

U toku procesa uništavanja naoružanja mogućnosti povređivanja radnika su raznovrsne i veoma izražene. Radnik se može povrediti u svim fazama procesa rada počev od prijema, istovara, transporta naoružanja pa do samog izvršenja procesa uništavanja, odnosno rada na mašinama (presama) za plastično deformisanje. Zaštita radnika koji rade na poslovima uništavanja naoružanja obezbeđuje se prvenstveno konstrukcionim rešenjem mašina ili ugradnjom odgovarajućih sistema zaštite.

Pri rešavanju konkretnog sistema zaštite mora se voditi računa o:

- izboru odgovarajućeg konstrukcionog materijala;

- pogodnom oblikovanju i prilagođavanju predmeta rada;
- postavljanju u kućište delova koji imaju opasna kretanja;

- vrsti izolacionih materijala za zaštitu od udara električne struje, za termičku zaštitu, zaštitu od buke, vibracija i sl.;

- primeni odgovarajuće mehaničke i električne opreme i instalacija (uređaja za zaštitno blokiranje, uređaja za zaštitu od električnog udara, zaštitu od preopterećenja mašine);

- što većoj automatizaciji procesa.

Zaštita radnika od mehaničkog povređivanja može se ostvariti različitim konstrukcionim rešenjima, kao što su: zaštitne naprave, uređaji, blokade, oklopi i dr.

Zaštitne naprave imaju ulogu da spreče pristup ruku ili drugih delova tela radnika do opasnog prostora u zoni pokretnih delova mašine. Mogu biti u obliku ograde, prepreke, štitnika, poklopca, vratašca, oklopa, kućišta, branika i slič- 
no. Konstruisane su tako da budu čvrste $\mathrm{i}$ otporne na udare, da svojim položajem i delovanjem ne stvaraju nove izvore opasnosti, da se ne mogu skidati sa mašine bez upotrebe specijalnih alata, da ne smetaju radniku pri obavljanju odgovarajućih operacija i slično.

Zaštitni uređaji imaju ulogu da štite mašinu od preopterećenja i spreče havariju ili zaštite radnika od povređivanja. Na mašinama kod kojih se aktiviranje izvršnog dela vrši dvoručnim komandama ne sme istovremeno da se radi nožnom komandom ili nekim drugim uređajem za aktiviranje. Ovi uređaji se primenjuju na presama, makazama za sečenje i sličnim mašinama.

Zaštitnim blokadama obezbeđuje se međuzavisnost delovanja zaštitnih naprava ili uređaja i mašine, odnosno njenih delova, kao i bezbedan rad, odnosno zaustavljanje mašine u slučaju otkaza ili drugih neželjenih pojava u procesu rada (sprečavanje istovremenog odvijanja različitih operacija i ograničavanje dužine hoda izvršnog dela mašine). Zaštitni oklopi sprečavaju dodir opasnih delova mašine. Oblik zaštitnog oklopa mora da bude prilagođen delovima mašine oko kojih postoji opasna zona. Oklopi ne smeju imati oštre uglove i ivice, jer bi time i sami predstavljali opasnost za radnike.

Uzročno-posledični lanac od opasnih zona na mašinama, preko nepažnje i netipičnih postupaka radnika do akcidenta, odnosno povrede (nezgode), među najznačajnijim su interaktivnim uticajima radnog procesa na radnika neposrednog izvršioca u toku procesa uništavanja naoružanja. Jedan od načina zaštite u toku uništavanja naoružanja na hidropneumatskim presama prikazan je na slici 6 .

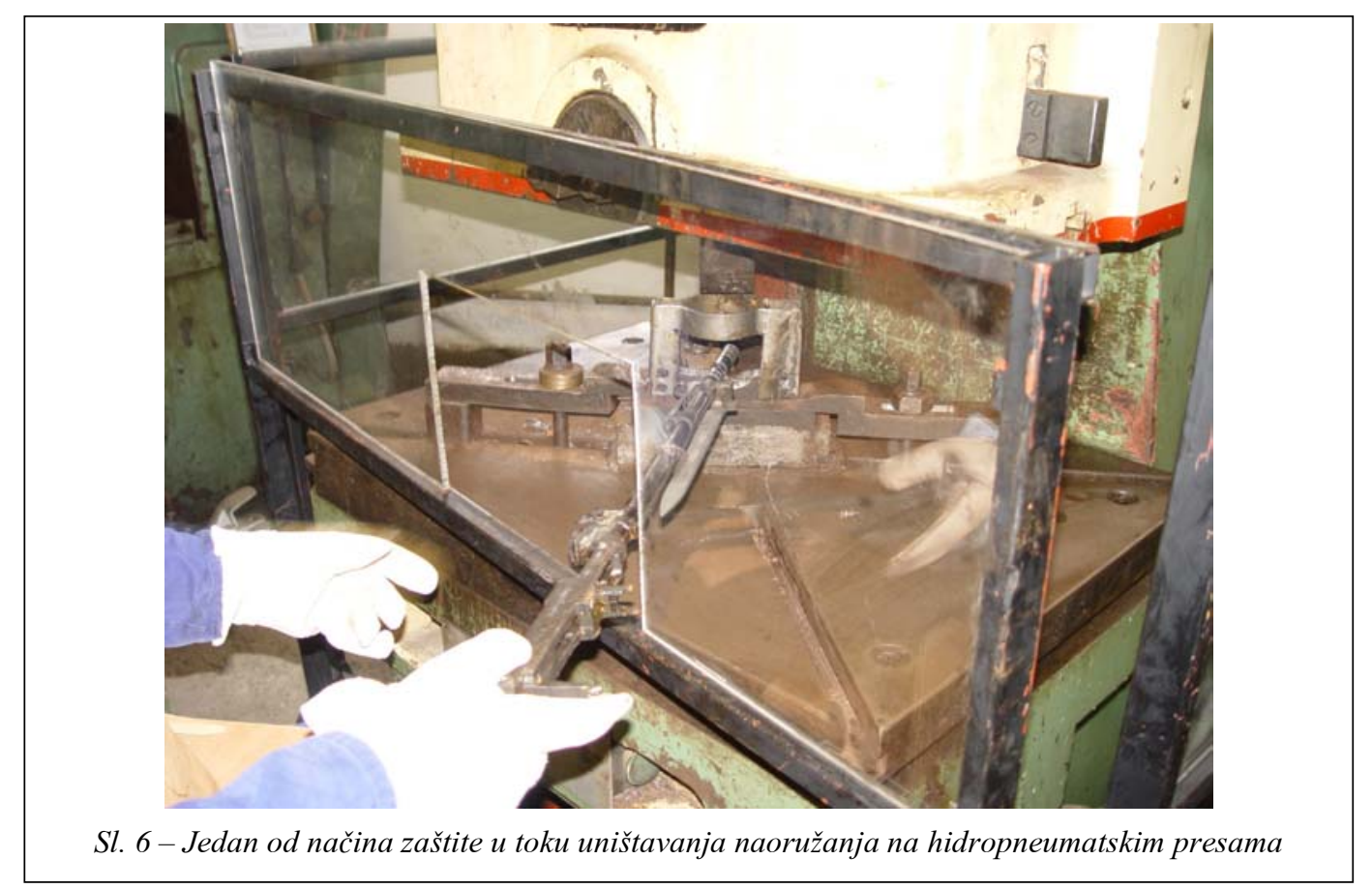




\section{Zaključak}

Uništavanje malog i lakog naoružanja u Tehničkom remontnom Zavodu u Čačku je aktivnost od velikog značaja za međunarodnu afirmaciju naše Vojske i zemlje u celini. Postupci uništavanja prikazani u ovom radu dobili su visoku ocenu nadležnih i kontrolnih organa, a i svih drugih koji su imali priliku da se upoznaju sa ovom akcijom. Ona je izazvala i veliku medijsku pažnju i bila afirmativno predstavljena. Mogućnost kontrole uništenog naoružanja $u$ svakoj fazi procesa, a i naknadno za svaki pojedinačni primerak, odnosno fabrički broj, najveća je prednost metode uništavanja naoružanja u TRZ Čačak. Takođe, ova metoda je i veoma rentabilna, uzimajući u obzir troškove radne snage i materijala koji su minimalni.
Da bi se ova složena aktivnost realizovala uz što manju mogućnost narušavanja bezbednosti okoline i povređivanja radnika - neposredih izvršilaca, primenjene su odgovarajuće mere zaštite na radu. Na primerima primenjenih zaštitnih mehanizama na konkretnim mašinama i uređajima pri procesu uništavanja naoružanja, ali i pri drugim radnim operacijama, pokazano je da se sa relativno malim materijalnim ulaganjima nivo zaštite i bezbednosti uopšte može podići na viši nivo, ne remeteći pri tome odvijanje propisanih tehnologija i postupaka rada.

Literatura:

[1] Uništavanje malog i lakog naoružanja - prezentacija, Tehnički remontni zavod, Čačak, 2003.

[2] OSHA standards: Concepts and Techniques of Machine Safeguarding, US Department of Labor, 1992.

[3] Janković, Ž., Jaćimović, D.: Koncepcija bezbednosti i zaštite na radu u procesu održavanja mašina i uređaja, XXIX naučno-stručni skup HIPNEF 2004, Vrnjačka Banja, 2004. 